\title{
POSTOPERATIVE SURVIVAL RESULTS OF PATIENTS WITH STAGE I-II MALIGNANT PLEURAL MESOTHELIOMA IN AN ENDEMIC AREA
}

\author{
Kermenli Tayfun, ${ }^{1}$ Azar Cebrail ${ }^{2}$ \\ ${ }^{1}$ Thoracic Surgery Department, Istanbul Aydin University, Istanbul, Turkey \\ ${ }^{2}$ Department of Chest Diseases Medicalpark Elazıg Hospital, Elazıg, Turkey
}

Primljen/Received 10. 06. 2020. god.

Prihvaćen/Accepted 10. 07. 2020. god.

\begin{abstract}
Introduction: The accepted treatment option for malignant pleural mesothelioma (MPM) is multimodality treatment including surgery, chemotherapy and radiotherapy. In this study, we aimed to evaluate the results of patients who underwent surgical resection for multimodality treatment due to MPM at our clinic between July 2015 and October 2019.
\end{abstract}

Method: The results of 13 patients who underwent surgical treatment for MPM in our clinic were evaluated retrospectively. Patients' demographic structure, regions where they live, symptom presentation, disease localization, biopsy diagnosis, type of surgical treatment, choice of neoadjuvant or adjuvant chemotherapy, postoperative complications and survival outcomes were evaluated.

Results: The mean survival time was 19.6 months. Six patients were still under follow-up. One patient whose postoperative pathology was reported as mixed type had the worst survival with 13 months and the best survival was 32 months in the patient who underwent postoperative hyperthermic chemotherapy with pleural decortication. Four patients died due to local recurrence and general condition disorder, and two patients died after peritonitis carcinomatosis and ascites.

Conclusion: Epitheloid type multimodality treatment and intrapleural hyperthermic chemotherapy may be a good choice in patients with the stage I and II malignant mesothelioma without surgical comorbidity.

Key words: mesothelioma, decortication, asbestos, pleura, malignant.

\section{INTRODUCTION}

Asbestos exhibits pathogenic properties depending on the diameter - length, exposure dose, duration of the asbestos fibers deposited on the pleural surface af- ter exposure and the body's ability to break down asbestos. These results in benign asbestos plaques or malignant pleural mesothelioma (MPM) (1). MPM continues to be an endemic disease especially in our country. In Turkey, every year an average 500-600 patients are estimated to receive new diagnosis (2). Despite all advances in chemotherapy and oncologic treatment options, the survival time of the disease is still very short $(3,4)$.

Malignant pleural mesothelioma has three histological subtypes, epitheloid, sarcomatoid and mixed. It is the most common epitheloid type (55-60\%) with the relatively good prognosis (5). Multimodality therapy, which includes thoracic surgery, oncology and radiation oncology, is the accepted world-wide option in the treatment of MPM (5). It is recommended that surgical + hyperthermic chemotherapy or radiotherapy to be applied only to surgery, followed by chemotherapy and incision areas together (6).

The aim of the surgery is to reduce the complaints such as shortness of breath and pain that may develop due to the disease, to improve the quality of life of the patient and to prolong the survival time. In addition, radical resection should be provided in macroscopic disease associated with lung parenchyma (7). In this study, we aimed to evaluate the results of patients who underwent surgical resection for MPM in our clinic between July 2015 and October 2019.

\section{MATERIAL AND METHODS}

The results of patients who underwent surgical treatment for MPM in our clinic were evaluated retrospectively from the hospital records. A total of 13 patients who underwent surgery was included in the study. Patients who received only chemotherapy and did not 
undergo surgery were excluded. Patients' demographic structure, region of residence, symptom presentation, disease localization, biopsy, type of surgical treatment, choice of neoadjuvant or adjuvant chemotherapy, postoperative complications and survival outcomes were evaluated. In patients, preoperative and postoperative staging was performed according to TNM 8th edition. Before surgery, all patients were evaluated by a multidisciplinary team, including a thoracic surgeon, oncologist and radiation oncologist. As a result of the biopsies performed, surgery was planned for the patients whose pathology was epitheloid type. Surgical or neoadjuvant treatment decision in all patients was made in the oncological council. Neoadjuvant therapy was given in cases considered to be inappropriate for surgery and accepted as advanced stage.

\section{RESULTS}

Eleven patients were male and 2 was female. The mean age was found to be $63.1 \pm 6.41$ (53 - 77). Eleven of the patients were from the endemic regions in terms of asbestos exposure in Elazig, Turkey and the surrounding provinces, and two patients came from Iraq. At the time of admission, the first symptom was dyspnea in 8 patients, back pain in 3 patients, and pleural effusion on chest X-ray in 2 patients. Posteroanterior and lateral chest radiographs of all patients were positive findings. Afterwards, patients underwent the contrast-enhanced thorax computed tomography (CT), and after MPM diagnosis the patients were staged with Positron Emission Tomography (Pet - CT). Chest radiography, thorax CT and Pet-CT were used as imaging methods in all patients. The mean SUV max was found to be $2.06 \pm 4.08(1.2-9.4)$. Localization included pleural effusion and pleural thickening on the right side in 10 patients and on the left side in 3 patients (Table I).

Eight patients $(61.5 \%)$ presented with recurrent pleural effusion after tube thoracostomy and thoracentesis were diagnosed with video-assisted thoracoscopic surgery (VATS) and one patient $(7.7 \%)$ with anteri-

Table 1. Demographic findings, presentation symptoms and tumor localization

\begin{tabular}{|c|c|c|c|}
\hline & & Patients number (n : 13) & $\%$ \\
\hline \multirow{2}{*}{ Gender } & Female & 2 & 15.4 \\
\hline & Male & 11 & 84.6 \\
\hline \multirow{3}{*}{ Symptoms at admission } & No symptom & 2 & 15.4 \\
\hline & Back pain & 3 & 23.1 \\
\hline & Dyspnea & 8 & 61.5 \\
\hline \multirow{2}{*}{ Tumor Localization } & Left & 3 & 23,1 \\
\hline & Right & 10 & 76,9 \\
\hline
\end{tabular}

Table 2. Diagnosis methods, neoadjuvant treatment, preoperative tumor stage, surgical methods and hyperthermic chemotherapy rate (VATS: Video-assisted thoracoscopic surgery, EPP: Extrapleural pneumonectomy, P/D: Total decortication, excisions of tumor tissue on the pericardium and diaphragm, TP/D: Total pleural decortication, iaphragm and pericardial resection)

\begin{tabular}{|l|l|c|c|}
\hline \multirow{4}{*}{ Diagnostic methods } & & $\begin{array}{c}\text { Patients number } \\
\text { (n : 13) }\end{array}$ & $\%$ \\
\hline \multirow{4}{*}{ Preoperative Stage } & Thoracotomy & 1 & 17,7 \\
\cline { 2 - 4 } & Thoracentesis & 4 & 30.8 \\
\cline { 2 - 4 } & VATS & 8 & 61.5 \\
\hline \multirow{4}{*}{ Neoadjuvant treatment } & Stage IA & 3 & 23.1 \\
\cline { 2 - 4 } & Stage IB & 5 & 38.4 \\
\cline { 2 - 4 } & Stage II & 4 & 30.8 \\
\hline \multirow{3}{*}{ Hypertermic Chemol Method } & EPP & 4 & 30.8 \\
\cline { 2 - 4 } & P/D & 1 & 7.7 \\
\cline { 2 - 4 } & TP/D & 2 & 15.4 \\
\hline
\end{tabular}


Table 3. Postoperative complications and tumor stage

\begin{tabular}{|l|l|c|c|}
\hline & & $\begin{array}{c}\text { Patients } \\
\text { number }\end{array}$ & \% \\
\hline \multirow{2}{*}{$\begin{array}{l}\text { Postoperative } \\
\begin{array}{l}\text { Complications } \\
(\mathbf{:}: \mathbf{6}, \mathbf{\%} 46.2)\end{array}\end{array}$} & Expansion defect and subcutaneous emphysema & 1 & 7,7 \\
\cline { 2 - 4 } & Atrial fibrillation & 2 & 15,4 \\
\cline { 2 - 4 } $\begin{array}{l}\text { Postoperative } \\
\text { Tumor Stage }\end{array}$ & Prolonged air leak & 3 & 23.1 \\
\cline { 2 - 4 } & Stage IA & 2 & 15.4 \\
\cline { 2 - 4 } & Stage IB & 6 & 46.2 \\
\hline
\end{tabular}

or mini thoracotomy. Four patients $(30.8 \%)$ who applied for the first time were diagnosed with MPM after thoracentesis. All patients had a diagnosis of epitheloid type mesothelioma. Three patients had received $4 \mathrm{cu}-$ res of pemetrexed and cisplatin chemotherapy as a neoadjuvant treatment prior to surgery (Table 2). According to TNM 8th edition, 5 patients were Stage IA, 4 patients were Stage IB and 4 patients were Stage II in preoperative staging. ECOG scores were 2 in 8 patients, 1 in 3 patients, and 0 in 2 patients.

Standard posterolateral thoracotomy incision was opened to the patients. Two different thoracotomies were performed from the 5 th and 8 th intercostal spaces from the same incision. Ten patients $(76.9 \%)$ underwent total pleural decortication, diaphragm and pericardial resection (TP, D group). One patient (7.7\%) underwent extra pleural pneumonectomy (EPP group), diaphragm and pericardial resection, and two patients (15.4\%) underwent total decortication, excisions of tumor tissue on the pericardium and diaphragm (P, D group) and primary repair after resection. The diaphragm and pericardial integrity were not impaired in this patient. Mesh was used for pericardial and diaphragmatic reconstruction in patients who underwent diaphragmatic and pericardial resection. Six patients received hyperthermic intrapleural chemotherapy with cisplatin at a dose of $100 \mathrm{mg} / \mathrm{m}^{2}$ relative to the body surface (Table 2).

In the postoperative period, 3 patients had prolonged air leakage, and 2 patients had atrial fibrillation, 1 patient had expansion defect and subcutaneous emphysema. No side effects related to hyperthermic chemotherapy were seen in the postoperative period. The average length of stay in the intensive-care unit of the patients was 1.5 (1-4) days, and the average length of hospital stay was 6.1 days (5-9). Postoperative pathology was reported as epitheloid type in 12 patients and mixed type in 1 patient. According to TNM 8 staging system, Stage IA: $2(15.4 \%)$ patients, Stage IB: $6(46.1 \%)$ patients and Stage II: 5 (38.5\%) patients were classified (Table III). In the postoperative period, 3 patients who were operated following neoadjuvant therapy we- re given 2 cycles of chemotherapy, and 10 patients who underwent direct surgery were given 6 cycles of pemetrexed and cisplatin chemotherapy. Patients were routinely given radiotherapy to surgical incision lines. One patient with mediastinal recurrence and one patient with femoral metastasis received regional radiotherapy.

The patients were followed up with the thorax and abdominopelvic CT in the postoperative period. Patients with suspected recurrence in tomography images were rechecked with PET-CT. When all patients were evaluated, the mean survival time was $19.6 \pm 4.76$ (13-32) months. Seven patients were still under follow-up. One patient whose postoperative pathology was reported as mixed type had the worst survival with 13 months and the best survival was found to be 32 months in the patient who underwent postoperative hyperthermic chemotherapy with P,D group. Four patients died due to local recurrence and general condition disorder, and two died after peritonitis carcinomatosis and ascites.

\section{DISCUSSION}

Malignant pleural mesothelioma is a malignancy with high mortality and predominance of asbestos exposure (8). In our series, the mean survival was 19.6 months which is consistent with the literature. The majority of patients present with dyspnea due to pleural effusion. In our series, the most common presenting symptom was dyspnea at $66.7 \%$. Chest radiography, Thorax CT or Pet - CT are the recommended methods for diagnosis (9).

Minimal invasive techniques should be used when selecting the biopsy method. Thoracentesis should be the first choice in diagnosis, but the diagnostic value has been reported to be very low. In a study by Lovrenski et al. (10), fluid samples from 49 patients with MPM were examined and as a result, only $29 \%$ of the patients were diagnosed as pathological malignant. This necessitates invasive biopsy techniques in patients with suspected malignancy and asbestos exposu- 
re. Eren et al. (11), in their study in Diyarbak2r, an endemic region for asbestos, and in 28 undiagnosed patients with pleural effusion, suggested VATS as a diagnostic method with a high diagnostic value of $96.5 \%$ and a low complication rate. In our series, VATS was the most frequently used diagnostic method in 8 (61.5 $\%)$ patients.

The International Mesothelioma Interest Group (IMIG) recommends the treatment of multimodality in malignant pleural mesothelioma. They are reported that the combination of surgery, radiotherapy and chemotherapy may increase the success of treatment $(12,13)$. Because of the aggressive nature of MPM, patients in the group that may benefit from surgery should be carefully selected when planning multimodality treatment $(14,15)$. It has been shown that long-term survival in MPM is impossible if metastasis to the mediastinal lymph nodes is detected $(16,17$, 18 ). In one of our patients, subcarinal lymph node involvement was detected in the postoperative pathology and the survival time was 13 months. However, the fact that the pathology result was mixed in this patient prevented us to determine whether lymph node positivity or pathological subtype had an effect on the course of the disease.

Different options may be preferred for surgical treatment in patients. One of them is extra pleural pneumonectomy, which is the en - block resection of the lung, parietal pleura decortication, pericardium and diaphragm. Thus, there are some who argue that a radical cytoreductive surgery is performed in MPM, and the same study emphasizes that it is not possible to perform R0 resection (19). On the other hand, there is a group that argues that macroscopic resection is sufficient to replace the morbidity and complications imposed by EPP $(20,21)$. In this case, extended pleural decortication or partial resection are recommended according to the diaphragm and pericardial involvement along with the total pleural decortication of the surgery (22). When we look at the preferred surgical technique in our patients, we saw that we performed total pleural decortication, diaphragm and pericardial resection surgery in general $(76.9 \%)$. In the literature, the survival of these patients is short and therefore, parenchymal protective surgical techniques should be preferred more (21-24).

In recent years, there have been published articles suggesting an increasing rate of intrapleural hyperthermic chemotherapy. Cisplatin $(25,26)$ is the most commonly used and recommended active substance for this purpose. In a study conducted by Burt et al. (27) in which 104 patients completed the treatment and published Phase I, it was shown that Ciplastin and Gemcitabine could be combined. We used Cisplatin-based chemotherapy in 3 patients who underwent hyperthermic chemotherapy; however, due to the limited number of patients, no statistical evaluation was made in terms of contribution to survival. In our patient series, early postoperative mortality was not seen, and the complication rate was $46.2 \%$ in accordance with the literature. In the postoperative period, no patient required transfusion due to perioperative bleeding. In our study, no significant finding was found in terms of prognostic factors.

Because of the small number of patients in our study, its retrospective nature and the patient series did not meet a certain standard, and we had some limitations. These limitations indicate that we are not sufficient to evaluate the effect of surgery + hyperthermic chemotherapy or surgery alone on survival, and randomized controlled trials are needed in this area. It is difficult to reach larger series in terms of mesothelioma surgery, and therefore the necessity of multicenter studies is obvious.

\section{CONCLUSION}

Malignant pleural mesothelioma, which is still endemic disease in our country and which is expected to increase with the urban transformation, is still a public health problem. As seen in the literature, there is no recommended treatment option for MPM at the level of definitive evidence. Multimodality therapy and intrapleural hyperthermic chemotherapy may be a good choice in selected patients.
Abbreviations
SUVmax - Maximum standardized uptake value
TNM - Tumor Node Metastasis
ECOG - Eastern Cooperative Oncologic Group

Conflict of Interests: The authors declare that there are no conflicts of interest related to this article.

Funding: None

\section{Licensing}

This work is licensed under a Creative Commons Attribution 4.0 International (CC BY 4.0) License. 


\title{
Sažetak
}

\section{REZULTATI POSTOPERATIVNOG PREŽIVLJAVANJA PACIJENATA SA PLEURALNIM MALIGNIM MEZOTELIOMOM STADIJUMA I-II U ENDEMSKOM PODRUČJU}

\author{
Kermenli Tayfun, ${ }^{1}$ Azar Cebrail ${ }^{2}$ \\ ${ }^{1}$ Thoracic Surgery Department, Istanbul Aydin University, Istanbul, Turkey \\ 2 Department of Chest Diseases Medicalpark Elazıg Hospital, Elazıg, Turkey
}

Uvod: Lečenje malignog pleuralnog mezotelioma (MPM) je multimodalno i uključuje hirurško lečenje, hemoterapiju i radioterapiju. U ovoj studiji cilj nam je bio da evaluiramo rezultate pacijenata koji su podvrgnuti hirurškoj resekciji u cilju multimodalnog lečenja MPM na našoj Klinici, u periodi između jula 2015. i oktobra 2019. godine.

Metod: Rezultati 13 pacijenata koji su podvrgnuti hirurškoj terapiji MPM na našoj Klinici su retrospektivno evaluirani. Analizirani su demografske karakteristike pacijenata, mesto boravka, simptomi bolesti, lokalizacija bolesti, nalaz biopsije, tip hirurškog tretmana, izbor neoadjuvantne i adjuvantne hemoterapije, postoperativne komplikacije i preživljavanje.

Rezultati: Srednji period preživljavanja bio je 19,6 godina. Šest pacijenata se još uvek pratilo. Jedan

\section{REFERENCES}

1. Senyigit A, Coskunsel M, Topcu F, Is2k R, Babayigit C. Malignant pleural mesothelioma: evaluation of clinical, radiological and histological features in 136 cases. Tuberkuloz ve Toraks Dergisi. 2000; 48(1): 26-34.

2. Metintas S, Metintas M, Ucgun I, Oner U. Malignant mesothelioma due to environmental exposure to asbestos: follow-up of a Turkish cohort living in a rural area. Chest. 2002; 122(6): 2224-9.

3. Turk F, Yuncu G, Ozturk G. Mezotelyomada tani ve tedavi amacli cerrahi yaklasimlar. Pam Med J. 2012; 5(3): 105-9.

4. Kang SR, Bok JS, Lee GD, Choi SH, Kim HR, Kim DK, et. al. Surgical options for malignant mesothelioma: a single-center experience. Korean J Thorac Cardiovasc Surg. 2018; 51(3): 195-201

5. Bozlar U, Ors F, Yildirim D, Battal B, Saglam M, Nural MS. Atypical malignant mesothelioma characterized with massive effusion: computed tomography findings. Firat Med J. 2009; 14(1): 78-80.

6. Sugarbaker PH. Intra-abdominal manifestations of pleural mesothelioma. Ann Transl Med. 2017; 5(11): 231.

7. Waller DA. Lung-sparing total pleurectomy: the surgical option of choice in malignant pleural mesothelioma? Eur J Cardiothorac Surg. 2013; 44(1): 123-4.

8. Tanrikulu AC, Abakay O, Sezgi C,Sen HS, Abakay A. Comparison of supportive treatment and pleurodesis in patients with malignant pleural mesothelioma. Dicle Med J. 2012; 39(4): 509-12.

9. Armato SG 3rd, Francis RJ, Katz SI, Ak G, Opitz I, Gudmundsson E, et. al. Imaging in pleural mesothelioma: A re- pacijent čiji je postoperativni patološki nalaz potvrdio mešoviti tip tumora je imao najkraći period preživljavanja od 13 meseci, a najduže preživljavanje od 32 meseca bilo je kod pacijenta koji je podvrgnut postoperativnoj hipertermičnoj hemoterapiji sa pleuralnom dekortikacijom. Četiri pacijenta su umrla zbog lokalne rekurentne pojave tumora i opšteg poremećaja zdravstvenog stanja. Dva pacijenta su umrla nakon peritonealne karcinomatoze i ascitesa.

Zaključak: Epiteloidni tip multimodalnog tretmana i intrapleuralna hipertermička hemoterapija mogu biti dobar izbor lečenja kod pacijenata sa stadijumom I-II malignog mezotelioma bez hirurških komorbiditeta.

Ključne reči: mezoteliom, dekortikacija, azbestoza, pleura, maligni.

view of the 14th International Conference of the International Mesothelioma Interest Group. Lung Cancer. 2019; 130: 108-14.

10. Lovrenski A, Panjkovic M, Tegeltija D, Latinovic LT, Krcedinac J. The role of cytological evaluation of pleural fluid in diagnosing malignant mesothelioma. Med Pregl. 2012; 65(1-2): 5-8.

11. Eren S, Balci AE, Ulku R, Esme H, Eren MN. Role of Video-Assisted Thoracoscopic Surgery (VATS) in pleural effusions. Tuberk Toraks. 2002; 50(1): 53-8.

12. MacRae RM, Ashton M, Lauk O, Wilson W, O'Rourke $\mathrm{N}$, Simone CB 2nd, et. al. The role of radiation treatment in pleural mesothelioma: Highlights of the 14th International Conference of the International mesothelioma interest group. Lung Cancer. 2019; 132: 24-7.

13. Schröder C, Opitz I, Guckenberger M, Stahel R, Weder W, Förster R, et.al. Stereotactic Body Radiation Therapy (SBRT) as salvage therapy for oligorecurrent pleural mesothelioma after multi-modality therapy. Front Oncol. 2019; 9: 961.

15. Noiret B, Eveno C. Bidirectional chemotherapy allowing surgery and HIPEC for malignant peritoneal mesothelioma. Pleura Peritoneum. 2019; 4(2): 20190011.

15. Franceschini D, De Rose F, Cozzi S, Renna I, Franzese C, Di Brina L, et. al. Volumetric modulated arc therapy after lung sparing surgery for malignant pleural mesothelioma: a single institution experience. Clin Lung Cancer. 2020; 21(1): 86-93.

16. Tokat AO, Kutlay H. Gene therapy in malignant mesothelioma. Tuberk Toraks. 2003; 51(4): 456-60.

17. Hassan M, Mercer RM, Maskell NA, Asciak R, McCracken DJ, Bedawi EO, et. al. Survival in patients with malignant pleural effusion undergoing talc pleurodesis. Lung Cancer. $2019 ; 137$ : 14-8. 
18. Kai Y, Tsutani Y, Tsubokawa N, Ito M, Mimura T, Miyata Y, et. al. Prolonged post-recurrence survival following pleurectomy/decortication for malignant pleural mesothelioma. Oncol Lett. 2019; 17(3): 3607-14.

19. Rokicki W, Rokicki M, Wojtacha J, Rydel MK. Malignant mesothelioma as a difficult interdisciplinary problem. Kardiochir Torakochirurgia Pol. 2017; 14(4): 263-7.

20. Scherpereel A, Astoul P, Bass P, Berghmans T, Clayson H, de Vuyst P, et. al. Guidelines of the European Respiratory Society and the European Society of Thoracic Surgeons for the management of malignant pleural mesothelioma. Eur Respir J. 2010; 35(3): 479-95.

21. Hasegawa S. Extrapleural pneumonectomy or pleurectomy/decortication for malignant pleural mesothelioma. Gen Thorac Cardiovasc Surg. 2014; 62(9): 516-21.

22. Opitz I, Weder W. A nuanced view of extrapleural pneumonectomy for malignant pleural mesothelioma. Ann Transl Med. 2017; 5(11): 237.

23. Kostron A, Friess M, Inci I, Hillinger S, Schneiter D, Gelpke H, et. al. Propensity matched comparison of extrapleural pneumonectomy and pleurectomy/decortication for mesothelioma patients. Interact Cardiovasc Thorac Surg. 2017; 24(5): 740-6.

24. Shahin Y, Wellham J, Jappie R, Pointon K, Majewski A, Black E. How successful is lung-preserving radical surgery in the mesothelioma and radical surgery-trial environment? A case-controlled analysis. Eur J Cardiothorac Surg. 2011; 39(3): 360-3.

25. Richards WG, Zellos L, Bueno R, Jaklitsch MT, Jänne PA, Chirieac LR, et al. Phase I to II study of pleurectomy/decortication and intraoperative intracavitary hyperthermic cisplatin lavage for mesothelioma. J Clin Oncol. 2006; 24(10): 1561-7.

26. Ambrogi MC, Bertoglio P, Aprile V, Chella A, Korasidis S, Fontanini G, et. al. Diaphragm and lung-preserving surgery with hyperthermic chemotherapy for malignant pleural mesothelioma: A 10-year experience. J Thorac Cardiovasc Surg. 2018; 155(4): 1857-66.

27. Burt BM, Richards WG, Lee HS, Bartel S, Dasilva MC, Gill RR, et.al. A phase I trial of surgical resection and intraoperative hyperthermic cisplatin and gemcitabine for pleural mesothelioma. J Thorac Oncol. 2018; 13(9): 1400-9.

\section{Correspondence to/Autor za korespondenciju}

Kermenli Tayfun

Olgunlar Mh. Atatürk Bulvarı No: 5

Elazig / Turkey

Email address: tayfunkermenli@gmail.com

Phone mobile: +90530 0150226

Fax: +90424 2348013 